\title{
UPAYA MENINGKATKAN KEMAMPUAN MEMBILANG MELALUI BERMAIN LOTTO ANGKA PADA ANAK KELOMPOK B TK DHARMA WANITA ROWO
}

\author{
Tri Haryanti \\ Taman Kanak-Kanak Dharma Wanita Rowo \\ e-mail: triharyanti12345@gmail.com
}

\begin{abstract}
Ability to say children is the ability of children to count by calling one by one to determine the number or number of objects. Lotto is an educational game used in learning activities in children. The use of lottery media numbers is a form of recognizing numbers in early childhood. The rationale for the emergence of this problem is still the low ability to say children of the Rowo B TK Dharma Wanita Group. The purpose of this study is 1) to find out how to play lotto numbers that can improve the ability to say, children, 2) to understand the ability to remember the ability to count children through playing lotto numbers in children B TK Dharma Wanita Rowo Kandangan Group Semester II 2017/2018 Academic Year. The subjects of this study were students of the Group B TK Dharma Wanita Rowo donated by 25 children. The research was conducted in February 2018. Data collection methods used were observation, documentation, and interviews. Based on the results of the research and discussion, it can be concluded that through the lotto numbers game can improve the ability to count children in the TK B Group of Dharma Wanita Rowo Kandangan Temanggung Semester II 2017/2018 Academic Year. This is evidenced by the increase. The increase only reached $20 \%$, then after the increase in Cycle I it increased to $52 \%$, and Cycle II to $84 \%$, has reached $80 \%$. This success is marked by the child being able to lift by pointing objects, connecting / pairing symbols with objects and writing numbers..
\end{abstract}

Key words: Ability To Say, Lotto Numbers

\begin{abstract}
Abstrak
Kemampuan membilang anak adalah kemampuan anak dalam menghitung dengan menyebut satu per satu untuk menentukan banyak atau jumlah benda. Lotto adalah alat permainan edukatif yang biasanya digunakan dalam kegiatan pembelajaran pada anak. Penggunaan media lotto angka merupakan pengenalan bilangan pada anak usia dini. Dasar pemikiran sehingga muncul permasalahan ini adalah masih rendahnya kemampuan membilang anak Kelompok B TK Dharma Wanita Rowo. Tujuan dari penelitian ini adalah : 1) untuk mengetahui bahwa bermain lotto angka dapat meningkatkan kemampuan membilang anak, 2) untuk mengetahui besarnya peningatan kemampuan membilang anak melalui bermain lotto angka pada anak Kelompok B TK Dharma Wanita Rowo Kandangan Semester II Tahun Pelajaran 2017/2018 .Subyek penelitian ini adalah peserta didik Kelompok B TK Dharma Wanita Rowo berjumlah 25 anak. Pelaksanaan penelitian pada bulan Pebruari 2018. Metode pengumpulan data yang digunakan adalah observasi, dokumentasi dan wawancara. Berdasarkan hasil penelitian dan pembahasan, maka dapat disimpulkan bahwa melalui bermain lotto angka dapat meningkatkan kemampuan membilang anak di Kelompok B TK Dharma Wanita Rowo Kandangan Temanggung Semester II Tahun Pelajaran 2017/2018. Hal ini dibuktikan dengan adanya peningkatan kemampuan membilang anak sebelum tindakan hanya mencapai 20\%, kemudian setelah diadakan perbaikan pada Siklus I meningkat menjadi 52\%, dan Siklus II menjadi $84 \%$, telah memenuhi persentase maksimum yang telah ditentukan yaitu $80 \%$. Keberhasilan ini ditandai dengan anak mampu membilang dengan menunjuk benda, menghubungkan/ memasangkan lambang bilangan dengan benda dan menulis angka.
\end{abstract}

Kata Kunci: Kemampuan Membilang, Lotto Angka 


\section{PENDAHULUAN}

Pendidikan anak usia dini dilaksanakan dengan prinsip bermain sambil belajar atau belajar seraya bermain. Bermain sebagai tempat berkomunikasi dalam penyelenggaraan pendidikan bertujuan mengembangkan sikap, perilaku yang didasari oleh nilai-nilai agama, moral dan norma-norma yang dianut oleh masyarakat. Usia dini merupakan usia yang sangat efektif untuk mengembangkan berbagai potensi yang dimiliki anak-anak. Upaya pengembangan ini dapat dilakukan melalui berbagai bidang pengembangan kognitif. Pemahaman tentang bilangan atau angka merupakan bagian dari pengembangan kognitif anak.

Mengenal konsep bilangan adalah kemampuan anak mengurutkan bilangan, berhitung, menjumlahkan, dan menghubungkan. Kegiatan pengenalan konsep bilangan 1-10 di kelompok B TK Dharma Wanita Rowo seringkali masih mengalami kendala atau kesulitan. Pada anak kelompok B kegiatan berhitung masih merupakan hal yang perlu diperhatikan dan penanganan secara sungguh-sungguh.

Berdasarkan pengamatan terhadap pengembangan kognitif di Kelompok B TK Dharma Wanita Rowo ditemukan adanya masalah rendahnya tingkat kemampuan dalam memahami konsep membilang. Hal ini ditandai pada setiap diberikan kegiatan berhitung, jumlah anak yang bisa menghitung hanya 5 anak dari 25 anak yang ada di kelompok B, pada saat guru memberikan kegiatan pengembangan berhitung permulaan menggunakan angka 1-10 anak-anak kurang menyenangi kegiatan tersebut, dalam kegiatan pengenalan konsep bilangan, anak-anak kelompok B hanya bisa menyebutkan urutan bilangannya saja, anak masih belum paham atau belum mengerti simbol angka 1-10.

Dari beberapa hal yang ditemukan di Kelompok B TK Dharma Wanita Rowo dalam kegiatan membilang mengalami kendala atau kesulitan yang dijumpai dalam proses kegiatan belajar mengajar. Hal tersebut disebabkan karena strategi pembelajaran yang diberikan guru kurang tepat dan media yang digunakan sangat terbatas. Sehubungan dengan masalah rendahnya tingkat kemampuan anak Kelompok B TK Dharma Wanita Rowo dalam hal ini yaitu membilang, peneliti ingin melakukan perbaikan pembelajaran melalui penelitian tindakan kelas dengan judul "Upaya Meningkatkan Kemampuan Membilang Melalui Bermain Lotto Angka pada Anak Kelompok B TK Dharma Wanita Rowo Kecamatan Kandangan Kabupaten Temanggung Semester II Tahun Pelajaran 2017/2018”. Dengan pelaksanaan perbaikan pembelajaran melalui penelitian tindakan kelas ini diharapkan akan meningkatkan kemampuan anak Kelompok B TK Dharma Wanita Rowo terhadap konsep membilang.

\section{Identifikasi Masalah}

1. Kemampuan anak kelompok B TK Dharma Wanita Rowo dalam membilang masih kurang baik karena belum memenuhi standar Tingkat Pencapaian Perkembangan yang ditetapkan dalam Permendiknas.

2. Kurang efektifnya penggunaan media untuk pembelajaran membilang di kelompok B TK Dharma Wanita Rowo.

\section{Pembatasan Masalah}

Diperlukan adanya pembatasan masalah agar peneliti lebih terfokus dan keterbatasan peneliti dalam melakukan identifikasi masalah di atas, maka peneliti hanya membatasi permasalahan dengan mengoptimalkan pemahaman kognitif anak dalam membilang melalui bermain lotto angka dengan kegiatan yang menarik dan disukai anak.

\section{Rumusan Masalah}

Berdasarkan latar belakang masalah yang telah dikemukakan diatas, rumusan masalah dari penelitian ini adalah :

1. Bagaimana pelaksanaan bermain lotto angka dapat meningkatkan kemampuan membilang pada anak Kelompok B TK Dharma Wanita Rowo Kecamatan Kandangan Kabupaten Temanggung Semester II Tahun Pelajaran 2017/2018?

2. Berapa besar peningkatan kemampuan membilang pada anak Kelompok B TK Dharma Wanita Rowo Kecamatan Kandangan Kabupaten Temanggung Semester II Tahun Pelajaran 2017/2018 setelah dilakukan perbaikan pembelajaran dengan bermain lotto angka?

\section{Tujuan Penelitian}

1. Untuk mengetahui pelaksanaan bermain lotto angka dapat meningkatkan kemampuan membilang pada anak Kelompok B TK Dharma Wanita Rowo Kecamatan Kandangan Kabupaten Temanggung Semester II Tahun Pelajaran 2017/2018.

2. Untuk mengetahui besarnya peningkatan kemampuan membilang pada anak Kelompok B TK Dharma Wanita Rowo Kecamatan Kandangan Kabupaten Temanggung Semester II Tahun Pelajaran 2017/2018 setelah dilakukan perbaikan pembelajaran dengan bermain lotto angka. 


\section{METODE PENELITIAN \\ Tempat Penelitian}

Penelitian dilakukan di TK Dharma Wanita

Rowo Kecamatan Kandangan Kabupaten Temanggung sebagai tempat penelitian pembelajaran di TK tempat tugas peneliti sendiri, tentunya akan memudahkan bagi peneliti dalam memperoleh data dan sekaligus hasil dari penelitian akan langsung dapat dirasakan.

\section{Waktu Penelitian}

Penelitian dilaksanakan pada semester II tepatnya pada bulan Pebruari 2018. Untuk perbaikan pembelajaran dilaksanakan selama dua siklus, yaitu Siklus I dan Siklus II dengan empat kali pertemuan.

\section{Subjek Penelitian}

Subjek penelitian tindakan kelas ini adalah siswa kelompok B TK Dharma Wanita Rowo tahun ajaran 2017/2018 berjumlah 25 anak, terdiri dari 14 anak laki-laki dan 11 anak perempuan.

\section{Data dan Sumber Data}

Penelitian ini menggunakan sumber data primer dan data sekunder. Sumber data primer diperoleh dari hasil belajar anak yang berupa wawancara pada aspek perkembangan kemampuan kognitif. Sedangkan sumber data sekunder diperoleh dari data hasil observasi yang peneliti lakukan terhadap anak selama kegiatan berlangsung, berupa daftar penilaian, dokumentasi, arsip-arsip resmi yang dapat mendukung hasil penelitian yang diperoleh dari hasil raport, dan daftar hadir anak

\section{Teknik dan Alat Pengumpulan Data}

\section{Observasi}

Observasi merupakan teknik pengumpulan data dengan cara mengamati setiap kejadian yang sedang berlangsung dan mencatatnya dengan alat observasi tentang halhal yang akan diamati dan diteliti (Wina Sanjaya, 2011 : 86). Observasi dilakukan terhadap peningkatan kemampuan mengenal bilangan melalui bermain lotto pada anak Kelompok B TK Dharma Wanita Rowo Kecamatan Kandangan Kabupaten Temanggung. Pengamatan ini dilakukan dengan menggunakan lembar observasi.

2. Wawancara

$$
\text { Wawancara adalah metode }
$$
pengumpulan data dengan jalan bertanya untuk mendapatkan informasi dengan cara bertanya secara langsung kepada responden. Sebelum melakukan wawancara, peneliti membuat daftar pertanyaan untuk memperoleh data tentang keadaan TK Dharma Wanita Rowo, baik kondisi TK maupun anak didiknya, dalam penelitian ini peneliti mengadakan wawancara dengan guru dan kepala sekolah. Dari hasil wawancara ini dapat diketahui respon anak terhadap pembelajaran dan kesulitan-kesulitan yang dihadapi dalam meningkatkan kemampuan membilang.

3. Dokumentasi

Menurut Lexy J. Moleong (2005 : 163) metode pengumpulan data dokumentasi adalah metode pengumpulan data dengan cara mempelajari dokumen-dokumen, yaitu bahan tertulis baik yang bersifat eksternal maupun internal yang berkaitan dengan masalah yang dibahas dalam penelitian. Dokumentasi dalam penelitian ini bertujuan untuk mendapatkan data yang dapat mendukung keakuratan data hasil observasi seperti karakteristik subyek penelitian dan data identitas anak.

\section{Analisa Data}

Dalam analisis data ini dilakukan perbandingan antara Siklus I dan Siklus II, maka analisis data ini menggunakan deskriptif komparatif, yaitu mendeskripsikan kondisi lapangan yang dapat dilihat pada gambaran obyek penelitian yang telah diperoleh dengan tujuan untuk mengetahui peningkatan kemampuan mengenal huruf anak. Kemudian data tersebut dikomparasikan dengan tinjauan pustaka sebagai tolok ukur penelitian sehingga dapat diambil kesimpulan. Analisis data dapat dilakukan melalui tiga tahap, yaitu reduksi data adalah kegiatan menyeleksi data dengan fokus masalah, mendeskripsikan data sehingga data yang telah diorganisasi bermakna, dan membuat kesimpulan berdasarkan deskripsi data.

Kemampuan membilang anak diukur dengan menggunakan analisis kualitatif yang merupakan bentuk angka dengan rumus sebagai berikut:

$$
\mathrm{P}=\underset{\mathrm{N}}{\underline{\mathrm{F}}} \times 100 \%
$$

Keterangan :

$\mathrm{P}$ : prosentase yang diharapkan

$\mathrm{F}$ : hasil yang dicapai anak

$\mathrm{N}$ : jumlah anak keseluruhan

\section{Indikator Keberhasilan}

Indikator kinerja atau indikator keberhasilan yang diharapkan dalam penelitian ini adalah hasil belajar anak dapat meningkat, sekurang-kurangnya $80 \%$ dari seluruh anak dan dengan meningkatnya hasil belajar maka 
keaktifan anak dalam mengikuti kegiatan pembelajaran meningkat.

Adapun indikator yang diharapkan dalam kognitif terutama pada pembelajaran membilang yaitu:

Tabel 1. Kisi-kisi Instrumen Observasi Kemampuan Membilang

\begin{tabular}{|l|l|l|l|l|}
\hline Indikator & \multicolumn{3}{|l|}{ Penilaian } & \\
\cline { 2 - 5 } & BB & MB & BSH & BSB \\
\hline Anak mampu & & & & \\
membilang dengan \\
menunjuk benda \\
(mengenal konsep \\
bilangan dengan benda- \\
benda) & & & & \\
\hline $\begin{array}{l}\text { Anak mampu } \\
\text { menghubungkan/mema } \\
\text { sangkan lambang } \\
\text { bilangan dengan benda- } \\
\text { benda }\end{array}$ & & & & \\
\hline $\begin{array}{l}\text { Anak mampu menulis } \\
\text { angka }\end{array}$ & & & & \\
\hline
\end{tabular}

Keterangan :

$\begin{array}{ll}\text { BB } & \text { : Belum Berkembang } \\ \text { MB } & \text { : Mulai Berkembang } \\ \text { BSH } & \text { : Berkembang Sesuai Harapan } \\ \text { BSB } & \text { : Berkembang Sangat Baik }\end{array}$

\section{Prosedur Penelitian}

\section{Perencanaan Tindakan}

Penyusunan rancangan tindakan, didasarkan pada hasil penjajagan awal. Secara rinci perencanaan mencakup tindakan yang akan dilakukan untuk memperbaiki, meningkatkan atau merubah perilaku dan sikap yang diinginkan sebagai solusi dari suatu permasalahan. Perlu disadari bahwa perencanaan ini bersifat fleksibel dalam arti dapat berubah sesuai dengan kondisi nyata yang ada. Dalam melakukan penelitian kemampuan kognitif melalui bermain lotto angka, peneliti harus mempersiapkan segala sesuatunya dan membuat secara detail setiap langkah kegiatan agar mencapai tujuan yang diharapkan. Dalam penelitian ini kegiatan yang dilakukan adalah:

a. Merencanakan pembelajaran yang akan diterapkan dalam proses belajar mengajar yaitu dengan bermain lotto angka yang menarik.

b. Menentukan pokok bahasan dan menyusun Rencana Pelaksanaan Pembelajaran (RPPH)

c. Menyiapkan alat peraga yang diperlukan yaitu lotto angka.

d. Mengatur kelas/posisi tempat. e. Menyiapkan format tanya jawab dan lembar observasi atau instrumen yang akan digunakan untuk memantau hasil kegiatan pembelajaran

2. Pelaksanaan Tindakan

Pelaksanaan tindakan menyangkut apa yang dilakukan peneliti sebagai upaya perbaikan, peningkatan atau perubahan yang dilaksanakan berpedoman pada rencana tindakan. Jenis tindakan yang dilakukan dalam PTK hendaknya selalu didasarkan pada pertimbangan teoritik dan empirik agar hasil yang diperoleh berupa peningkatan kinerja dan hasil program yang optimal. Dalam penelitian ini peneliti melakukan kegiatan sesuai dengan rencana kegiatan harian.

Secara rinci urutan pembelajaran pada indikator membilang dengan lotto angka adalah sebagai berikut :

a. Peneliti mengatur posisi tempat duduk anak.

b. Peneliti membicarakan kegiatan yang akan dilaksanakan kepada anak tentang bermain lotto angka.

c. Peneliti menyediakan alat dan bahan yaitu lotto angka.

d. Peneliti bersama anak-anak membahas tentang membilang dengan menunjuk benda, memasangkan lambang bilangan dengan benda dan menulis angka.

e. Anak-anak diberi tugas untuk membilang dengan menunjuk benda, memasangkan lambang bilangan dengan benda dan menulis angka.

f. Anak-anak satu persatu bergiliran membilang dengan menunjuk benda, memasangkan lambang bilangan dengan benda dan menulis angka.

\section{Observasi}

Kegiatan observasi dalam PTK dapat disejajarkan dengan kegiatan pengumpulan data dalam penelitian formal. Dalam kegiatan ini peneliti mengamati dan mencatat hasil atau dampak dari tindakan yang dilaksanakan terhadap anak dengan memakai instrumen yang telah dipersiapkan.

Selama melaksanakan tindakan pembelajaran peneliti dibantu teman sejawat mengamati dan mencatat semua aktifitas anak dengan menggunakan lembar observasi selama pembelajaran kognitif dengan lotto angka.

4. Refleksi

Pada dasarnya kegiatan refleksi merupakan kegiatan pengkajian secara menyeluruh terhadap semua informasi yang diperoleh saat kegiatan tindakan. Dalam kegiatan ini peneliti mengkaji, melihat, dan 
mempertimbangkan hasil-hasil atau dampak dari tindakan. Setiap informasi yang terkumpul perlu dipelajari kaitan yang satu dengan lainnya dan kaitannya dengan teori atau hasil penelitian yang telah ada dan relevan. Melalui refleksi yang mendalam dapat ditarik kesimpulan. Refleksi merupakan bagian yang sangat penting dari PTK yaitu untuk memahami terhadap proses dan hasil yang terjadi, yaitu berupa perubahan sebagai akibat dari tindakan yang dilakukan. Berdasarkan data yang sudah terkumpul dilakukan evaluasi untuk mnyempurnakan tindakan berikutnya.

Pada hakekatnya langkah-langkah PTK model Kemmis dan Mc Taggart berupa siklus dengan setiap siklus terdiri dari empat komponen yaitu perencanaan, pelaksanaan (tindakan), pengamatan (observasi), dan refleksi yang dipandang sebagai satu siklus. Setelah selesai Siklus I, dilakukan Siklus II dengan melewati alur yang sama sebagai perbaikan.

Berdasarkan pada hasil pengamatan selama penelitian pembelajaran kognitif melalui bermain lotto angka maka hasil observasi ditelaah, dicari kendala, selanjutnya dicari solusi untuk perencanaan perbaikan di siklus berikutnya.

Pada siklus berikutnya dilakukan tahapan-tahapan yang sama dengan siklus sebelumnya, tetapi didahului dengan perencanaan yang lebih matang agar kelemahan di siklus sebelumnya tidak terulang kembali

\section{HASIL PENELITIAN DAN PEMBAHASAN Kondisi Awal}

Anak Kelompok B TK Dharma Wanita Rowo yang terlibat dalam penelitian tindakan kelas ini berjumlah 25 anak, terdiri dari 14 anak laki-laki dan 11 anak perempuan. Pada kondisi awal, pembelajaran membilang yang dilakukan oleh guru dengan menggunakan papan tulis dan lembar kerja anak. Kadang-kadang guru juga menggunakan media kartu angka dan gambar dinding yang dimiliki oleh sekolah. Anak-anak tampak kurang antusias. Perhatian anak kurang fokus dan anak banyak bermain dengan temannya.

Sebelum melakukan penelitian tindakan kelas, peneliti melakukan pengamatan awal berupa kegiatan observasi kemampuan kognitif anak dalam kegiatan membilang tanpa instrumen penelitian. Hasil observasi menunjukkan kemampuan anak masih belum memuaskan. Banyak anak yang belum mampu membilang, memasangkan lambang bilangan dengan jumlah benda yang sesuai, dan menulis angka 1-10 dengan benar dan masih memerlukan bantuan guru.

Pratindakan dilakukan untuk mengetahui kemampuan anak dalam membilang sebelum dilakukan penelitian tindakan kelas. Skor pratindakan nanti akan dibandingkan dengan skor setelah dilakukan tindakan Siklus I dan II sehingga dapat diketahui pengaruh penggunaan lotto angka dalam meningkatkan kemampuan membilang anak.

Berikut merupakan hasil pengamatan awal terhadap peningkatan kemampuan membilang anak Kelompok B TK Dharma Rowo Kandangan Temanggung.

Tabel 2. Data Kemampuan Membilang Anak

\begin{tabular}{|l|l|l|}
\multicolumn{3}{|c}{ Kondisi Pra Siklus } \\
\hline Nilai & Jumlah Anak & Persentase \\
\hline BB & 17 & $68 \%$ \\
\hline MB & 3 & $12 \%$ \\
\hline BSH & 5 & $20 \%$ \\
\hline BSB & 0 & $0 \%$ \\
\hline
\end{tabular}

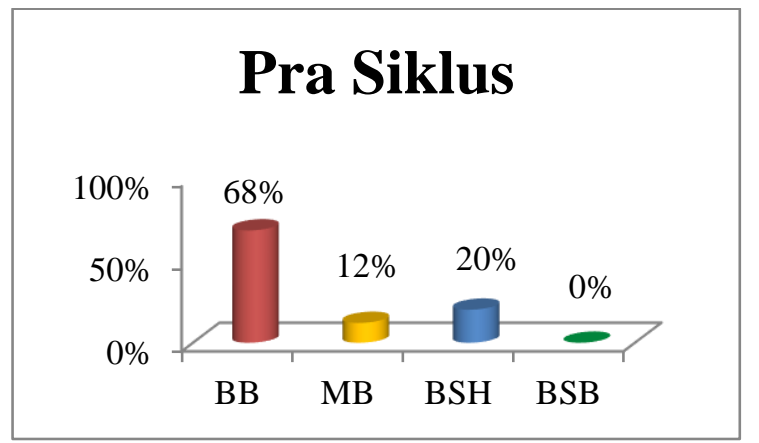

Grafik 1. Kemampuan Membilang Anak Kondisi Pra Siklus

Keterangan :

BB : Belum Berkembang

MB : Mulai Berkembang

BSH : Berkembang Sesuai Harapan

BSB : Berkembang Sangat Baik

Berdasarkan hasil observasi tentang peningkatan kemampuan membilang melalui kegiatan bermain lotto angka sebelum tindakan dilakukan seperti diuraikan pada tabel di atas, diketahui bahwa anak yang menunjukkan kemampuannya dengan kriteria penilaian berkembang sesuai harapan sebanyak 5 anak atau $20 \%$ yang berarti anak mampu membilang dengan baik sesuai indikator yang ditetapkan yaitu anak membilang dengan menunjuk benda, menghubungkan/memasangkan lambang bilangan dengan benda-benda, dan menulis angka.

Uraian di atas menunjukkan bahwa kemampuan membilang anak belum termotivasi 
dengan baik. Keadaan ini menjadi alasan dalam upaya untuk meningkatkan kemampuan membilang anak Kelompok B TK Dharma Wanita Rowo Kecamatan Kandangan Kabupaten Temanggung Semester II Tahun Pelajaran 2017/2018 melalui kegiatan bermain lotto angka.

\section{Siklus I}

Pada setiap pertemuan, pengamat melakukan observasi dan mendokumentasikan tindakan yang dilakukan anak bersamaan dengan berlangsungnya tindakan. Observasi dilakukan terhadap anak, baik sebelum, saat, maupun sesudah tindakan dalam pembelajaran di kelas. Hasil observasi Siklus I berupa aktivitas anak selama proses pembelajaran berlangsung serta hasil belajar anak.

Peneliti melakukan pengamatan atau observasi terhadap kegiatan yang dilakukan oleh anak. Berdasarkan hasil pengamatan dalam kegiatan pembelajaran meningkatkan kemampuan anak dalam membilang, aktivitas pembelajaran membilang dengan menunjuk benda ternyata sudah mulai menarik minat anak. Kegiatan pembelajaran menghubungkan jumlah gambar dengan angka yang melambangkannya dan menulis angka pada Siklus I ini sudah mulai menarik minat anak tetapi nilainya masih kurang maksimal.

Pada saat mengerjakan lembar kerja menghubungkan/ memasanhkan lambang bilangan dengan benda, masih banyak anak yang keliru. Begitu juga dalam menulis angka, banyak anak yang masih menuliskan angka secara terbalik, terutama angka 6 dan 9. Walaupun masih banyak yang keliru, tetapi anak terlihat sangat antusias menyelesaikan tugasnya. Anak-anak sibuk sendiri dengan lembar kerja yang dikerjakannya. Hal ini menunjukkan bahwa anak tertarik terhadap kegiatan membilang.

Peneliti melakukan observasi didukung dengan instrumen observasi. Instrumen observasi ini digunakan untuk mengetahui pemahaman anak dalam menyebutkan bilangan dengan menunjuk benda, memasangkan/ menghubungkan lambang bilangan dengan benda, dan menulis angka.

Berdasarkan hasil tindakan pertemuan pertama pada Siklus I, maka diperoleh gambaran tentang hasil peningkatan kemampuan membilang anak yang menunjukkan kemajuan dibandingkan dengan kegiatan sebelum tindakan. Hasil peningkatan pada pertemuan pertama menunjukkan bahwa anak yang memperoleh kriteria penilaian berkembang sangat baik $0 \%$, kriteria berkembang sesuai harapan sebanyak 8 anak atau 32\%, kriteria mulai berkembang 5 anak atau 20\%, kriteria belum berkembang sebanyak 12 anak atau $48 \%$.

Sedangkan untuk pertemuan kedua Siklus I hasil peningkatan kemampuan membilang dengan bermain lotto angka menunjukkan bahwa anak yang memperoleh kriteria penilaian berkembang sangat baik $0 \%$, kriteria berkembang sesuai harapan sebanyak 13 anak atau 52\%, kriteria mulai berkembang 4 anak atau $16 \%$, kriteria belum berkembang sebanyak 8 anak atau $32 \%$.

Berdasarkan data di atas hasil peningkatan kemampuan membilang anak setelah dilakukan tindakan perbaikan pada Siklus I diketahui bahwa ada peningkatan kemampuan membilang anak melalui bermain lotto angka meskipun belum mencapai target yang diharapkan.

Tabel 3. Peningkatan Kemampuan Membilang Anak Siklus I

\begin{tabular}{|l|l|l|l|l|l|l|l|l|}
\hline Siklus I & \multicolumn{2}{|l|}{ BSB } & \multicolumn{2}{l|}{ BSH } & \multicolumn{2}{l|}{ MB } & \multicolumn{2}{l|}{ BB } \\
\hline Pertemuan & 0 & $\begin{array}{l}0 \\
\text { I }\end{array}$ & $\begin{array}{l}\% \\
\%\end{array}$ & $\begin{array}{l}32 \\
\%\end{array}$ & 5 & $\begin{array}{l}20 \\
\%\end{array}$ & 12 & $\begin{array}{l}48 \\
\%\end{array}$ \\
\hline Pertemuan & 0 & 0 & 13 & $\begin{array}{l}52 \\
\text { II }\end{array}$ & 4 & $\begin{array}{l}16 \\
\%\end{array}$ & 8 & $\begin{array}{l}32 \\
\%\end{array}$ \\
\hline
\end{tabular}

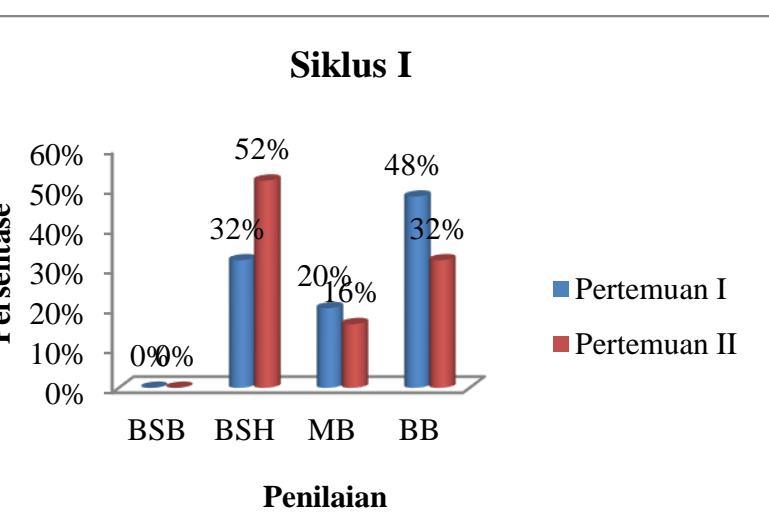

Grafik 2. Peningkatan Kemampuan Membilang Anak Siklus I

Dari hasil observasi menunjukkan adanya peningkatan jumlah anak yang mendapatkan penilaian dengan kriteria baik walaupun hasilnya belum optimal, pada pra siklus tercatat hanya $20 \%$ anak yang mendapat nilai dengan kriteria berkembang sesuai harapan meningkat menjadi $52 \%$ pada Siklus I.

Peneliti dan kolaborator membahas hal-hal yang menjadi masalah atau kendala pada pelaksanaan Siklus I. Dalam refleksi ini dibahas mengenai kendala-kendala yang dihadapi dalam Siklus I adalah sebagai berikut:

1. Belum semua anak dapat berkonsentrasi dalam mengikuti kegiatan. 
2. Peneliti belum memberi kesempatan pada anak untuk bertanya apabila ada yang kurang jelas.

3. Peneliti masih kurang menguasai kelas. Ada beberapa anak yang berbicara dengan anak lain pada saat peneliti sedang menyampaikan penjelasan.

4. Banyak kesalahan yang terjadi dalam menghubungkan/ memasangkan lambang bilangan dengan benda, anak dalam menulis angka juga seringkali terbalik-balik, seperti angka 6 dan 9, karena kemiripan kedua angka tersebut.

Melihat kondisi seperti tersebut di atas, maka diperlukan perbaikan dalam proses pembelajaran. Setelah berdiskusi dengan teman sejawat, maka disusun rencana perbaikan sebagai penyempurnaan pada tindakan kelas siklus berikutnya, antara lain:

1. Peneliti selalu mengingatkan dan memotivasi anak untuk memperhatikan penjelasan peneliti.

2. Peneliti memberi kesempatan anak untuk bertanya apabila ada penjelasan dari peneliti yang belum dipahami anak.

3. Peneliti berusaha untuk menguasai kelas dan membuat kegiatan yang menarik.

4. Peneliti memberikan keterangan yang lebih rinci mengenai angka. Untuk penulisan angka yang sering terbalik, peneliti meminta anak untuk latihan menebalkan angka terlebih dahulu sebelum menulis angka.

Dengan melihat hasil yang diperoleh dari

kedua pertemuan pada Siklus I, terjadi peningkatan pada kemampuan membilang, namun hasil pada Siklus I belum mencapai pada indikator keberhasilan yang diinginkan sehingga diperlukan pelaksanaan Siklus II.

\section{Siklus II}

Pada setiap pertemuan, peneliti melakukan observasi dan mendokumentasikan tindakan yang II dilakukan anak bersamaan dengan berlangsungnya tindakan. Observasi dilakukan terhadap anak, baik sebelum, saat, maupun sesudah tindakan dalam pembelajaran di kelas. Aktivitas anak pada Siklus II ini tampak lebih meningkat. Hal ini terlihat dari tingkat pemahaman anak dalam menerima penjelasan dari peneliti. Pada saat melakukan aktivitas permainan menghubungkan/ memasangkan lambang bilangan dengan benda, membilang dengan menunjuk benda, anak terlihat lebih bersemangat. Pada saat diberi penjelasan, perhatian anak juga lebih baik. Fakta ini membuktikan bahwa dalam Siklus II semua anak sudah dapat menyebutkan bilangan 1-10 dan sebagian besar anak sudah dapat menulis angka 1-10 dengan benar. Meskipun masih ada beberapa anak yang masih belum bisa menulis angka dengan benar, tetapi secara umum perkembangan anak dalam membilang sudah sangat baik. Anak-anak sudah mau menyelesaikan tugasnya.

Berdasarkan hasil tindakan pertemuan pertama pada Siklus II, maka diperoleh gambaran tentang hasil peningkatan kemampuan membilang anak yang menunjukkan kemajuan dibandingkan dengan kegiatan Siklus I. Hasil peningkatan pada pertemuan pertama menunjukkan bahwa anak yang memperoleh kriteria penilaian berkembang sangat baik $0 \%$, kriteria berkembang sesuai harapan sebanyak 17 anak atau 68\%, kriteria mulai berkembang 3 anak atau 12\%, kriteria belum berkembang sebanyak 5 anak atau $20 \%$.

Sedangkan untuk pertemuan kedua Siklus II hasil peningkatan kemampuan membilang dengan bermain lotto angka menunjukkan bahwa anak yang memperoleh kriteria penilaian berkembang sangat baik $0 \%$, kriteria berkembang sesuai harapan sebanyak 21 anak atau $84 \%$, kriteria mulai berkembang 2 anak atau $8 \%$, kriteria belum berkembang sebanyak 2 anak atau $8 \%$.

Berdasarkan data di atas, setelah dilakukan tindakan perbaikan pada Siklus II diketahui bahwa ada peningkatan kemampuan membilang anak melalui bermain lotto angka. Hasil belajar anak sudah sesuai dengan indikator pembelajaran yang ditetapkan yaitu $80 \%$ anak mampu membilang dengan baik ditandai dengan anak mampu membilang dengan menunjuk benda, anak mampu menghubungkan/ memasangkan lambang bilangan dengan benda, dan anak mampu menulis angka.

Tabel 4. Peningkatan Kemampuan Membilang Anak Siklus II

\begin{tabular}{|c|c|c|c|c|c|c|c|c|}
\hline Siklus II & \multicolumn{2}{|c|}{ BSB } & \multicolumn{2}{|c|}{ BSH } & \multicolumn{2}{|c|}{$\mathrm{MB}$} & \multicolumn{2}{|c|}{$\mathrm{BB}$} \\
\hline $\begin{array}{l}\text { Pertemuan } \\
\text { I }\end{array}$ & 0 & $\begin{array}{l}0 \\
\%\end{array}$ & 17 & $\begin{array}{l}68 \\
\%\end{array}$ & 3 & $\begin{array}{l}12 \\
\%\end{array}$ & 5 & $\begin{array}{l}20 \\
\%\end{array}$ \\
\hline $\begin{array}{l}\text { Pertemuan } \\
\text { II }\end{array}$ & 0 & $\begin{array}{l}0 \\
\%\end{array}$ & 21 & $\begin{array}{l}84 \\
\%\end{array}$ & 2 & $7 \%$ & 2 & $\begin{array}{l}8 \\
\%\end{array}$ \\
\hline
\end{tabular}

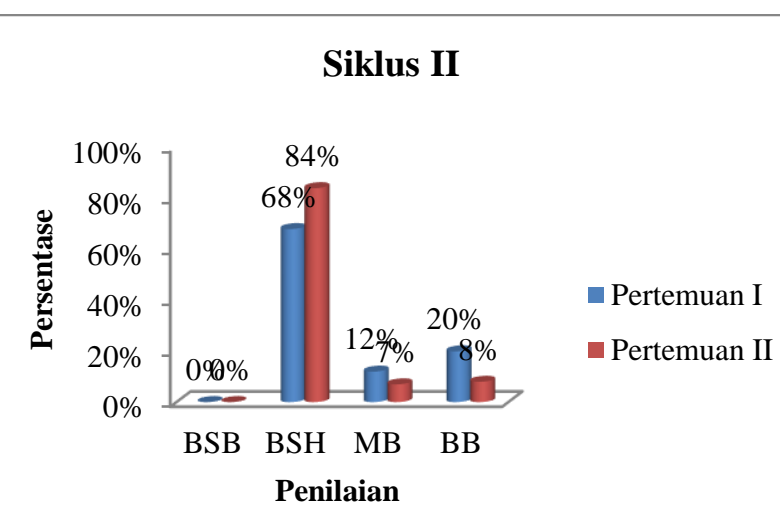

Grafik 3 Peningkatan Kemampuan Membilang Anak Siklus II 
Berdasarkan hasil penelitian mengenai kemampuan membilang pada Siklus II menunjukkan sudah memenuhi indikator keberhasilan, sehingga perbaikan pembelajaran dihentikan pada Siklus II. Peningkatan hasil penilaian kemampuan membilang meningkat pada setiap siklusnya dan sudah melampaui target minimal yang ditetapkan yaitu $80 \%$. Hal ini menunjukkan bahwa pembelajaran dengan bermain media lotto angka terbukti dapat meningkatkan kemampuan anak dalam membilang.

\section{Pembahasan Hasil Penelitian}

Berdasarkan pengamatan yang telah dilakukan sebelumnya, kemampuan membilang anak Kelompok B TK Dharma Wanita Rowo Kandangan masih kurang maksimal karena metode dan media pembelajaran yang kurang menarik. Untuk mengatasi kesulitan tersebut diperlukan suatu kegiatan yang dapat membantu perbaikan peningkatan kemampuan anak dalam membilang. Kegiatan tersebut adalah dengan bermain menggunakan lotto angka.

Pada dasarnya pembelajaran membilang dengan bermain lotto angka adalah mendekatkan anak pada obyek nyata. Lotto merupakan media visual yang mampu membantu anak dalam meningkatkan aspek perkembangan kognitif (Suryaningrum, 2012: 2). Penggunaan media lotto angka merupakan pengelanan bilangan pada anak usia dini. Dalam mengenalkan bilangan pada anak usia dini tentunya harus menarik, menyenangkan dan kreatif. Media lotto angka bisa dijadikan alternatif dalam pembelajaran matematika khususnya dalam konsep angka atau bilangan.

Pada akhir Siklus I telah terjadi peningkatan kemampuan anak yang cukup baik, baik dari kemampuan membilang dengan menunjuk benda, menghubungkan/ memasangkan lambang bilangan dengan benda dan menulis angka. Kemampuan anak pada saat pratindakan sebesar $20 \%$ meningkat menjadi 52\% pada akhir Siklus I. Meskipun terjadi peningkatan, tetapi hasilnya belum mencapai indikator keberhasilan yang diinginkan. Setelah dilakukan refleksi, diperlukan langkah selanjutnya untuk merencanakan kegiatan agar dicapai hasil yang lebih baik.

Pada Siklus II terjadi peningkatan yang lebih tinggi dari Siklus I. Kemampuan anak pada akhir Siklus II meningkat menjadi $84 \%$. Peningkatan yang sangat signifikan ini menunjukkan berhasilnya proses perencanaan berdasarkan refleksi hasil Siklus I. Hasil penilaian pada Siklus II telah mencapai kriteria berkembang sesuai harapan dan telah melampaui indikator keberhasilan yang ditetapkan sebesar $80 \%$.

Peningkatan kemampuan membilang anak dari kondisi pra siklus sampai Siklus II dapat dilihat pada tabel berikut :

Tabel 5. Peningkatan Kemampuan Membilang Anak Pra Siklus, Siklus I, Siklus II

\begin{tabular}{|l|l|l|l|l|}
\hline Siklus & BSB & BSH & MB & BB \\
\hline Pra Siklus & $0 \%$ & $20 \%$ & $12 \%$ & $68 \%$ \\
\hline Siklus I & $0 \%$ & $52 \%$ & $16 \%$ & $32 \%$ \\
\hline Siklus II & $0 \%$ & $84 \%$ & $8 \%$ & $8 \%$ \\
\hline
\end{tabular}

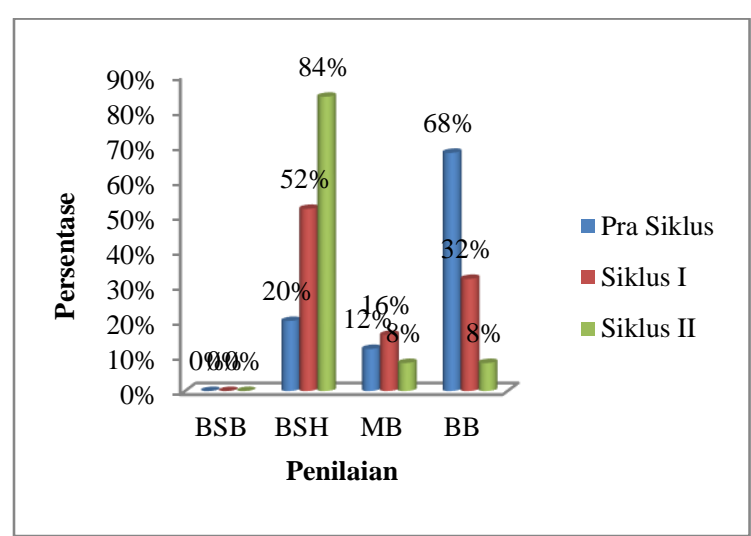

Grafik 4 Peningkatan Kemampuan Membilang Anak Pra Siklus, Siklus I, Siklus II

Dari hasil penelitian di atas dapat terlihat bahwa untuk meningkatkan kemampuan membilang anak dapat dilakukan melalui bermain lotto angka. Kegiatan bermain lotto angka pada Kelompok B TK Dharma Wanita Rowo Kandangan Temanggung dapat membantu anak untuk meningkatkan kemampuan membilang anak yang ditandai dengan anak mampu membilang dengan menunjuk benda, menghubungkan/ memasangkan lambang bilangan dengan benda dan menulis angka.

Penelitian ini sesuai dengan pendapat Sujiono (2008:8.34) yang menyatakan bahwa media lotto bermanfaat untuk merangsang perkembangan syaraf kognitif anak, mengembangkan kemampuan anak dalam memecahkan suatu masalah, dapat menjalin kerjasama dan bersosialisasi dengan teman kelompoknya saat memainkan media lotto, mengembangkan kemampuan anak dalam membedakan warna dan yang ada pada media lotto (melatih intelektual), mampu mengembangkan edukasi anggota tubuh baik tangan atau jari, mata, membiasakan anak bersosialisasi dengan teman-temannya karena permainan ini dapat dilakukan perorangan dan kelompok dan seru dijadikan permainan saat ada acara kelompok baik itu sekolah, keluarga. 
Sedangkan tujuan dari bermain lotto angka adalah untuk merangsang minat berhitung anak, merangsang kemampuan kognitif anak dalam konsep bilangan, mampu menghubungkan gambar/benda, benda dengan simbol yang melambangkannya, melatih keberanian, mengembangkan daya ingat.

\section{KESIMPULAN DAN SARAN Kesimpulan}

Berdasarkan hasil penelitian dan pembahasan yang telah dilakukan dapat disimpulkan bahwa pembelajaran dengan bermain lotto angka dapat meningkatkan kemampuan membilang anak kelompok B TK Dharma Wanita Rowo Kandangan Temanggung. Hal ini ditunjukkan dari adanya peningkatan kemampuan membilang dengan membilang dengan menunjuk benda, memasangkan/ menghubungkan lambang bilangan dengan benda dan menulis angka dari pratindakan sebesar $20 \%$, pada Siklus I menjadi $52 \%$ dan pada Siklus II meningkat menjadi $84 \%$. Sehingga tingkat pencapaian kemampuan membilang pada anak kelompok B TK Dharma Wanita Rowo telah tercapai.

Langkah-langkah pembelajaran dengan bermain lotto angka dilakukan dengan mengajak anak menyebutkan angka 1-10, menjelaskan cara menghubungkan/ memasangkan lambang bilangan dengan benda, memberi contoh cara menulis angka, menjelaskan cara mengisi LKA, bermain dengan lotto angka dan dilanjutkan pengisian LKA. Kegiatan dilakukan dengan berbagai variasi dalam setiap siklus untuk menghindari kebosanan anak.

Berdasarkan hasil penelitian dan pembahasan serta rumusan permasalahan yang telah ditetapkan sebelumnya, maka dapat disimpulkan bahwa melalui bermain lotto angka dapat meningkatkan kemampuan membilang anak di Kelompok B TK Dharma Wanita Rowo Kecamatan Kandangan Kabupaten Temanggung Semester II Tahun Pelajaran 2017/2018.

\section{Saran}

Berdasarkan hasil penelitian, maka dapat diusulkan beberapa saran sebagai berikut:

1. Media lotto angka dapat dijadikan alternatif pembelajaran untuk meningkatkan kemampuan membilang di Taman Kanakkanak. Guru dapat meggunakan lotto sesuai dengan pembelajaran yang sedang berlangsung, misalnya lotto angka, lotto warna, lotto pola.

1. Diharapkan pihak sekolah dapat menyediakan fasilitas untuk mendukung pembelajaran membilang dengan menggunakan media lotto angka.

\section{DAFTAR PUSTAKA}

Arikunto, Suharsimi. 2002. Prosedur Penelitian. Jakarta: Rineka Cipta.

Carol, Seefeld dan Barbara A. Wasik. 2008. Terjemahan: Pius Nasar. Pendidikan Anak Usia Dini. Jakarta: Indeks

Depdikbud. 2003. Kamus Besar Bahasa Indonesia. Jakarta : Balai Pustaka.

Hadjar, Ibnu. 1999. Dasar-dasar Metodologi Penelitian Kuantitatif dalam Pendidikan. Jakarta: Raja Grafindo Persada.

Hartati, Sofia. 2005. Perkembangan Belajar Pada Anak Usia Dini. Jakarta: Departemen Pendidikan Nasional.

Madya, Suwarsih. 1994. Panduan Penelitian Tindakan. Yogyakarta: Lembaga Penelitian IKIP Yogyakarta.

Moleong J.Lexy. 2005. Metodologi Penelitian Kualitatif. Bandung: Remaja Rosdakarya.

Musfiroh, Tadkiroatun. 2005. Bermain Sambil Belajar dan Mengasah Kecerdasan. Jakarta: Departemen Pendidikan Nasional.

Permendiknas No. 58 Tahun 2009 tentang Standar Pendidikan Anak Usia Dini.

Sanjaya, Wina. 2012. Media Komunikasi Pembelajaran. Jakarta: Kencana Prenada Group.

Sriningsih. 2009. Pembelajaran Matematika Terpadu untuk Anak usia Dini. Bandung: Pustaka Sebelas.

ST. Negoro dan B. Harahap. 2014. Ensiklopedia Matematika. Bogor: Ghalia Indonesia.

Sudaryanti. 2006. Pengenalan Matematika Anak Usia Dini. Yogyakarta: FIP UNY.

Sugianto, Mayke. 1995. Bermain, Mainan dan Permainan. Jakarta: Departemen Pendidikan dan Kebudayaan.

Sugiyono. 2009. Statistika untuk Penelitian. Bandung: CV Alfabeta 
Sujiono, Bambang. 2005. Metode Pengembangan Fisik. Jakarta: Universitas Negeri Jakarta. Sujiono, Yuliani Nurani. 2011. Konsep Dasar Pendidikan Anak Usia Dini. Jakarta: PT Indeks Sujiono. 2008. Metode Pengembangan Kognitif. Jakarta: Universitas Terbuka.

Suryaningrum, M. 2012. Pengaruh Media Lotto Warna dan Bentuk Terhadap Kemampuan Kognitif Anak Kelompok A di RA Al Islam Jetis Dagangan. Madiun: Jurnal Vol. 1, No. 1.

Suyanto, S. 2003. Konsep Dasar Pendidik an Anak Usia Dini. Yogyakarta: Universitas Negeri Yogyakarta.

Suyanto, Slamet. 2005. Dasar-Dasar Pendidikan Anak Usia Dini. Yogyakarta: Hikayat Publishing.

Tanjung, Husni Wardi. 2005. Bermain Melalui Gerak dan Lagu di Taman Kanak-Kanak. Jakarta: Departemen Pendidikan Nasional.

Tim Penyusun Kamus Pusat Bahasa. 2002. Kamus Besar Bahasa Indonesia. Edisi Ketiga. Jakarta: Balai Pustaka 